\title{
PROPOSTA DE PRODUÇÃO TEXTUAL PARA O ENSINO MÉDIO: COMO O PROFESSOR TECE ESTE INSTRUMENTO DIDÁTICO?
}

\author{
PROPOSED TEXTUAL PRODUCTION FOR HIGH SCHOOL: \\ HOW DOES TEACHER MAKE THIS EDUCATIONAL TOOL?
}

Débora Cristina do Nascimento Ferreira ${ }^{25}$

\begin{abstract}
RESUMO: Este artigo analisa uma proposta de produçăo textual direcionada para turmas do primeiro ano do Ensino Médio. O objetivo é investigar os princípios de ordem teórica e metodológica presentes em uma folha avulsa, da disciplina Redaçâo, utilizada para orientar o processo de produçáo do gênero textual lenda. 0 dado utilizado foi gerado via pesquisa-açăo, realizada no período de 2008 a 2012, em uma escola da rede privada de ensino, da cidade de Belém-PA. A escrita do docente é analisada a partir das contribuiçôes teóricas dos estudos aplicados, voltados para o ensino de produçáo escrita (BUNZEN, 2009; GOMES-SANTOS, 2010; ANDRADE, 2011). Como resultado geral, constatamos: (i) a natureza híbrida e intergenérica da escrita do texto docente (CORREA, 2006); (ii) o movimento de institucionalizaçăo de um ensino de escrita pautado pelas orientaçóes escolares já prestigiadas na escola-usina;26 (iii) indícios das orientaçôes da regulamentaçăo oficial vigente para o ensino de Português no Brasil.
\end{abstract}

Palavras-chave: Produçăo Textual; Escrita; Escola-usina.

ABSTRACT: This paper analyzes a textual production proposal directed to classes the first year of high school. The aim is to investigate the theoretical and methodological principles the teaching materials to guide teaching writing about legend textual genre. The data used were generated through action research performed on the period between 2008 and 2012 in a private school in Belém-PA city. The teacher"s writings are analyzed based on Applied Linguistic framework, specifically as regards Portuguese language teaching/learning (BUNZEN, 2009; GOMES-SANTOS, 2010; ANDRADE, 2011). The data analysis indicates that there is: (i) a hybrid and intergeneric writing (CORREA, 2006), as well advances and challenges in writing didactization process in factory-school; (ii) the institutional moviment of writing teaching according to school guidance already consecrated in factory-school; (iii) evidences of guidances of current oficial regulations for the teaching of portuguese in Brazil.

Keywords: Text; Writing; Factory - School.

25 Doutoranda em Linguística Aplicada pela Universidade Estadual de Campinas. Agradeço ao Conselho Nacional de pesquisa pelo apoio para a realizaçăo desta investigaçăo. E-mail: debi.nascimento@hotmail.com

26 A partir das contribuiçôes teóricas de Tardif e Lessard (2005), apresentamos a expressâo escola-usina em nossa dissertaçâo de mestrado, mais adiante neste artigo, vamos tecer algumas consideraçóes a respeito da expressăo e para maiores informaçôes cf. Ferreira, 2008. 


\section{INTRODUÇÃO}

A partir da segunda metade do século XX, o Brasil vivenciou o processo de democratizaçấo do ensino, o qual contribuiu de modo significativo para a chegada das classes populares à escola. Este acesso foi resultado de um longo processo de luta dos grupos populares pelo direito à educaçăo formal. Entretanto, o acesso infelizmente năo assegurou nem as condiçôes estruturais necessárias para a permanência destes grupos na instituiçấo escolar, nem a garantia da qualidade do ensino veiculado por esta. Em decorrência desse processo de democratizaçăo, passaram a ser utilizados manuais didáticos para fins de organizaçăo de conteúdos, de proposiçāo de aulas e de exercícios, material este outrora formulado e preparado pelos próprios docentes (SOARES, 1996, 2002a, b).

Nesse percurso, o livro didático (doravante LD) torna-se um dos principais instrumentos de trabalho do professor e passa a ser uma demanda na agenda das políticas educacionais brasileiras.27 Nesse cenário, Tardif (2002) apresenta duas importantes categorizaçóes para refletirmos acerca dos papeis da atividade docente, grosso modo, podemos dizer que trata-se da classificaçăo concernente aos professores "conceptores"28 (aqueles que, predominantemente, estariam envolvidos no processo de investigaçăo acadêmica e/ou de criaçâo de projetos didáticos, conforme a regulamentaçăo oficial vigente, para fins de avaliaçâo, de comercializaçâo e de circulaçâo de LDs) e aos "professores executores" (aqueles que, predominantemente, estariam envolvidos na tarefa de escolher os manuais por recomendaçăo de quem já os usou, ou utilizando critérios 29 definidos pelas equipes de docentes), competiria também a estes docentes a (re)criaçăo, a ressignificaçăo e a implementaçăo efetiva destes projetos de ensino nos mais diversos e multifacetados contextos educacionais do país (SOARES, 1996; BUNZEN, 2009).

A despeito da grande comercializaçăo de LDs, há grupos de ensino que assumem a responsabilidade pela produçáo e venda de seu próprio material didático (apostilados e folhas avulsas). Tendo em vista essa situaçăo, este artigo tem como objetivo analisar quais săo as orientaçôes de ordem teórica e metodológica, que estăo presentes em uma proposta de produçáo textual, produzida por uma docente da rede privada de ensino da cidade de Belém-PA, direcionada para turmas do primeiro ano do Ensino Médio, na disciplina Redaçăo. Assim sendo, este texto está organizado da seguinte maneira: (i) breve discussâo sobre ensino da escrita escolar, (ii) descriçấo e análise de uma proposta de produçâo construída por um professor.

27 Segundo Silva (1998, p. 3), “O livro didático passa a ser utilizado com mais frequência no Brasil na segunda metade da década de sessenta, com a assinatura do acordo MEC-USAID, em 1966, época em que săo editados em grande quantidade para atender a demanda de um novo contexto escolar em surgimento. Em 1985, criou-se o Programa Nacional do Livro Didático (PNLD). Porém, somente no início dos anos noventas o MEC passou a avaliá-los (projeto pedagógico difundido por meio dos Parâmetros Curriculares Nacionais (PCNs) e dos Guias do livro didático)".

28 A categorizaçăo executores e conceptores é cunhada por Tardif (2002).

29 Cabe lembrar que estes critérios que ainda nâo estariam bem precisos, delineados e descritos pela literatura. 


\section{INSCRIÇÃO DISCIPLINAR DA ESCRITA ESCOLAR}

A partir do século XIX, a recém-criada disciplina curricular Português tinha como foco o ensino de Gramática, ao lado da Retórica, da Oratória, da Poética e da Literatura. A "composiçâo" era ensinada nesta inscriçâo curricular, em especial, nas séries finais do intitulado ensino secundário nas aulas de Retórica e de Poética. Nesse contexto, ensinar a escrever estava diretamente ligado à tarefa de mimetizar os modelos literários de autores de prestígio da Literatura Vernácula. Considerava-se que o constante trabalho de imitaçăo dos bons modelos de escrita levaria ao aprendizado de uma língua una, homogênea, elaborada e completa em si mesma. Este modelo de ensino-aprendizagem "Beletrista" estava inserido em um sistema educacional, que tinha como finalidade oferecer uma formaçăo de natureza propedêutica a uma facçăo social específica: os filhos de uma elite agrária e aristocrática de um país dito republicano. Uma alteraçâo significativa deste quadro ocorreu somente na segunda metade do século XX (RAZZINI, 2000; SOARES, 2002; BUNZEN, 2006).

Nas décadas de 1960 e 1970, houve uma mudança bem notória relativa ao ingresso efetivo de uma considerável parcela da populaçấo que até entâo năo frequentava a escola e o contexto universitário, enfim: as classes populares invadem a catedral ${ }^{30}$. Isto implicou o ingresso de uma clientela heterogênea, advinda de contextos sociais, culturais, históricos, letrados múltiplos e diferenciados. Consequentemente, esta entrada implicou mudanças de ordem oficial, estrutural, pedagógica e curricular em relaçăo às disciplinas escolares. Paralelo a este contexto, já percebíamos uma discussáo pertinente ao ensino da escrita por uma perspectiva que passava a levar em conta a "criatividade do aluno". A leitura de textos serviria năo só para impulsionar "hábitos de leitura", mas também funcionaria como um "estímulo" para escrever; por sua vez, o texto produzido seria "fruto de um ato criativo", decorrente do estímulo do método ora utilizado. Mais adiante, outra perspectiva (uma abordagem textual e cognitiva) tomava o texto como suporte para desenvolver estratégias e habilidades de leitura e redaçăo. A leitura estaria voltada para o entendimento de diversas estratégias, já a produçấo estaria direcionada para discussâo de estratégias de planejamento, revisâo e editoraçấo. Nâo obstante, o texto, objeto de uso, de suporte, ainda náo se constituía efetivamente como objeto de ensino-aprendizagem da disciplina Português (ROJO e CORDEIRO, 2004).

Cabe mencionar que, nos anos 1970, a Lei de Diretrizes e Bases da Educaçâo (Lei n. ${ }^{\circ} 5.692$ /71) altera o nome da disciplina Língua Portuguesa: “Comunicaçăo e expressâo" para as primeiras séries do que hoje é considerado Ensino Fundamental (EF); "Comunicação em língua portuguesa" para as séries finais do EF; "Língua Portuguesa e Literatura Brasileira", para o (EM). Nessa época, pode-se perceber a influência da teoria da comunicaçấ, o foco do ensino estaria interligado ao desenvolvimento do uso da língua (entendida como código) e à capacidade de emitir e receber mensagens. As redaçôes escolares săo entâo concebidas como atos de comunicaçáo. Nesse contexto, o ensino de gramática já náo é o principal foco e o uso quase exclusivo de textos literários para o trabalho com leitura e escrita cede lugar à diversidade de textos provenientes das esferas de uso (SOARES, 2002b; BUNZEN, 2006; PIETRI, 2010).

30 Faço referência ao livro: LEITE, Lígia Chiappini M. Invasăo da catedral: literatura e ensino em debate. Porto Alegre: Mercado Aberto, 1983. 
Nesta conjuntura, é publicada uma determinaçăo oficial de suma relevância para o papel que o ensino de redaçáo ocuparia no cenário educacional do país. Trata-se do Decreto federal n. ${ }^{0}$ 79. 298, de 24 de fevereiro de 1977, que estabeleceu, a partir de janeiro de 1978, a obrigatoriedade da prova de redaçăo em Língua Portuguesa nos Vestibulares (BUNZEN, 2006). A publicaçăo deste decreto traz à tona duas situaçôes referentes ao contexto educacional daquela época. A primeira é a grande demanda pelos cursos universitários:

O extraordinário crescimento da demanda escolar em todos os níveis de ensino devido o inchaço cada vez maior da populaçăo urbana, pode ser medido pelo aparecimento de vários cursos superiores, (sobretudo dos cursos de filosofia, ciências e letras) e pelo aumento assombroso da matrícula nos cursos superiores, que cresceu 389\% no período 1960-1971. A corrida aos cursos superiores aumentou a competiçăo no vestibular, potencializou a funçăo preparatória do curso colegial, a qual se revelou ineficiente, propiciando o desenvolvimento dos "cursinhos" prévestibulares (RAZZINI, 2000, p. 112)

A segunda diz respeito à necessidade de inserçăo (retorno) da redaçăo aos exames vestibulares. A imposiçăo oficial implicou a criaçăo de uma "nova disciplina" no currículo, a fim de ensinar a fazer a chamada Redaçâo de Vestibular. Se, por um lado, esta medida nâo surtiu efeito no sentido de melhoria dos textos dos alunos, por outro lado, estas redaçôes serviram como objeto de estudo para vários pesquisadores brasileiros nas décadas de 1970, 1980 e 1990,31 instaurando assim um salutar debate sobre questóes essenciais para delinear novos rumos para a disciplina Língua Portuguesa. Por conta disso, destacamos algumas assertivas que consideramos relevantes, a saber:

(i) a constataçăo derecorrentes problemas de redaçăo concernentes ao uso normativo, à informatividade, à concatenaçấo de ideias, à ausência de posicionamentos críticos, mas também à presença de fenômenos linguísticos relevantes para refletirmos sobre traços característicos do português brasileiro em curso, vivo, dinâmico, oriundo dos usos reais da língua;

(ii) o conjunto de análises sinaliza para a necessidade de ensinar escrever, levando em consideraçáo as reais condiçóes de produçăo, a existência de um interlocutor, os propósitos comunicativos, a funcionalidade e a operacionalizaçăo da escrita em práticas situadas;

(iii) a crítica ao ensino balizado no uso de estratégias de preenchimento e de modelos prontos, centrados nos tipos textuais narrativo, descritivo e dissertativo, os quais năo garantiriam ao aluno, em tese, a condiçăo de produtor de textos;

(iv) a necessidade de construçáo de um arcabouço teórico-metodológico com base em estudos linguísticos, a fim de repensar năo só alternativas relativas às práticas de ensino de língua materna, mas também para melhoria dos materiais didáticos, constituiçáo de regulamentaçăo oficial orientadora da açăo docente, tentativa de (re)estruturaçăo de sistemas avaliativos e inserçâo de critérios de caráter textual e discursivo nestes aparelhos docimológicos. ${ }^{32}$

31 A saber: Viana (1976), Carone (1976), Fernandes (1976), Baccega (1977), Pécora (1977, 1989), Lemos (1977) Lima (1977), Mamizuka (1977), Negrăo (1977), Osakabe (1977), Val (1991), Brito (1995), Barros (1999), Sautchuk (2003), dentre outros.

32 Estas consideraçôes foram tecidas inspiradas basicamente a partir das leituras de Britto (1997); Pietri, 2010, Gomes-Santos (2010). 
Este conjunto de reflexóes implicou a convocaçăo de uma concepçăo de linguagem capaz de abarcar a natureza discursiva, ideológica, heterogênea, múltipla, transitória e complexa da língua (BAKHTIN, 1977). Trata-se de uma concepçâo enunciativa que permite compreender toda atividade de linguagem como o lugar de interaçấo, de conflito de interesses, de cultura, de intencionalidade. Nesse raciocínio, "a interaçâo verbal constitui, assim, a realidade fundamental da linguagem" (BAKHTIN, 1995, 123). A linguagem seria o espaço da criaçáo de efeitos de sentido e da réplica ativa em relaçấo ao processo enunciativo sócio-historicamente situado (TRAVAGLIA, 1996; BAKHTIN, 1995).

Nessa direçăo, escrever deveria ser uma tarefa de produçăo textual ("associada à ideia de trabalho, de processo"33) voltada para construçăo de textos diversos, oriundos dos usos cotidianos, dotados de finalidades específicas e situados em uma prática social escolar. Este encaminhamento didático conduz a um ensino mais procedimental e reflexivo e, consequentemente, menos transmissivo, tornando a sala de aula um espaço mais dialógico e interativo. Trata-se de convocar relaçóes discursivas estabelecidas entre os modos de agir, de pensar, de interpretar, de julgar a partir da memória discursiva dos sujeitos (BUNZEN, 2006; FURLANETTO, 2007; FERREIRA et al., 2014).

Podemos constatar que, apesar das contribuiçôes desta mencionada concepçâo de linguagem mais abrangente, das relevantes investigaçôes acadêmicas dos últimos quarenta anos, das significativas propostas de ensino de leitura, de produçăo e de reflexâo linguística lançadas por diferentes vertentes de estudo acadêmico, da publicaçáo dos Parâmetros Curriculares Nacionais (BRASIL, 1997, 1999), norteando a prática docente a eleger o texto como unidade básica de trabalho e os gêneros orais e escritos como objetos de ensino. Mesmo com todas essas contribuiçôes, a Redaçăo de Vestibular permanece plena como instrumento avaliativo, atualmente em amplitude nacional: é o caso do Exame Nacional do Ensino Médio (ENEM). A redaçăo é institucionalizada como requisito básico e obrigatório para ingresso no ensino superior e em inúmeros cargos do funcionalismo público, o que termina por legitimar e garantir o seu espaço no currículo de Língua Portuguesa, principalmente, no Ensino Médio.

Para Andrade (2011), a redaçăo escolar constitui uma "incógnita epistemológica", pois ora é tida como "năo texto", ora é tida como veículo para materializar outros textos típicos da produçâo didática e ora é tida como gênero. Tendo em vista estes pressupostos, podemos supor que, em alguma medida, o ensino de escrita é marcadoindiciado pela conjugaçăo de conhecimentos oriundos desta intricada e recente inscriçăo curricular de didatizaçăo do texto escrito na cultura escolar brasileira. Por conta disso, na próxima seçáo, procuraremos analisar uma proposta de escrita direcionada aos alunos do EM, buscando mostrar como a escritura docente pode convocar ecos, indícios, de diferentes filiaçóes que tentam orientar o professor a didatizar o texto escrito no âmbito escolar (CORREA, 2006).

33 Gomes-Santos (2010) expóe a escrita na prática escolar em três momentos: escrita como composiçăo "expressâo estética e efeito de inspiraçẫo", escrita como redaçăo "recorrente produçâa dissertaçăo escolar" e escrita como produçăo textual "associada à ideia de trabalho, de processo". 


\section{A ESCOLA-USINA E A PROPOSTA DE REDAÇÃO}

O locus de produçăo e circulaçăo da proposta de escrita que vamos analisar é um grupo de ensino particular, da cidade de Belém (PA) e o mote institucional é a aprovaçăo dos alunos nos vestibulares. Para Britto (1997), esta realidade é típica dos sistemas particulares de ensino, as chamadas escolas modulares, organizadas dentro dos moldes de cursinho: aulas apostiladas, super-especializaçâo das disciplinas, divididas em frentes de trabalho ${ }^{34}$ e o público-alvo, quase sempre, sâo os filhos das classes alta e média a quem prometem preparar para o ingresso no ensino superior.

Trata-se de um contexto típico da realidade brasileira: a escola-usina, caracterizada por: (i) tratar grupos numerosos de indivíduos, ao longo de vários anos, conforme um padrăo uniforme para alcançar resultados parecidos; (ii) subordinar estes sujeitos a "regras impessoais, gerais, abstratas, fixadas por leis e regulamentos" (idem, p. 24); (iii) impor um "sistema de vigilância, de puniçôes e recompensas" (idem) que extrapola os limites dos conteúdos a serem assimilados; (iv) o trabalho escolar- executado pelos agentes escolares: alunos, professores, inspetores- é padronizado, dividido, planificado e controlado (TARDIF e LESSARD, 2005; FERREIRA, 2008).

Nestas instituiçôes, os apostilados sâo os materiais didáticos que substituem os LDs, sendo complementados pelas folhas avulsas (reforço ao conteúdo já apresentado pelo professor, geralmente, as propostas de escrita e exercício complementares sáo veiculados neste instrumento). A escola delega ao professor ou à equipe de cada disciplina preparar estes materiais, embora o grupo de ensino, muitas vezes, assuma a autoria deste instrumento didático. A seguir, analisamos uma proposta de redaçâo intitulada "Gênero textual: Lenda", aplicada para cinco turmas ${ }^{35}$ do primeiro ano do EM, do grupo educacional supracitado. Cabe dizer que a análise será encaminhada, levando em conta uma perspectiva de cunho qualitativo, considerando os indícios da estrutura textual, temática e discursiva que sinalizam para diferentes perspectivas de ensino da escrita (GINZBURG, 1987; CORRÊA, 2006).

A proposta ${ }^{36}$ de produçâo de texto presente na folha avulsa está estruturada da seguinte maneira: (i) título; (ii) breve apresentaçâo do gênero lenda, usando referências de dicionários e da literatura especializada; (iii) contextualizaçấo do gênero no âmbito amazônico; (iv) boxe conclusivo de traços do gênero; (v) exercitaçáo do gênero: conceituaçấo e características de lenda urbana, em seguida, temos o texto "A moça do táxi", acompanhado de um exercício de seis questōes discursivas (focadas para identificar traços do tipo textual narrativo); (vi) enunciado-proposta, solicitando a escrita

34 A disciplina Língua Portuguesa é dividida em três frentes: Português, Literatura e Redaçăo, o que caracteriza a dita pedagogia da fragmentaçáo disciplinar, fortemente vinculada ao EM, articulada a uma formaçăo mais especializada voltada ao ensino superior, ao trabalho, dentre outros fins (MENDONÇA e BUNZEN, 2006). Nestas escolas, o ensino da Redaçáo é um campo fértil para acendrar o processo de exploraçâo/ precarizaçăo do trabalho docente. Pino (2009, p. 124) destaca características próximas ao perfil deste professor, a saber: múltiplas funçôes, sobrecarga de trabalho, baixa remuneraçāo, maior separaçăo entre concepçăo e execuçáo: isolamento e solidâo, dependência de materiais e "especialistas" externos (TARDIF, 2002).

35 Cada turma possui em média de sessenta a setenta alunos.

36 A proposta pode ser encontrada no anexo 1. 
de uma lenda, retratando a realidade amazônica e, por fim, um conjunto de sete tópicos designado "Orientaçóes para a produçăo textual".

É interessante atentarmos para o fato de que o título deste dispositivo didático "Gênero textual: Lenda" pode ser lido como uma resposta ao enunciado da regulamentaçấo oficial nacional, que orienta o professor a adotar o gênero como objeto de ensino e o texto como unidade de trabalho. $\mathrm{O}$ uso deste título e as referências conceituais utilizadas para definir lenda no início do material corroboram para a tentativa desta escrita professoral, de certo modo, buscar uma aproximaçâo entre os saberes escolares e os saberes de referência, o que concorreria para um processo de legitimaçâo desse conjunto de conhecimentos didáticos. Pode-se, entăo, dizer que o professor busca atender a orientaçăo oficial e acadêmica, mas singulariza este fazer ao propor isso em um dado molde didático. Por outro lado, a opçăo pela seleçăo lexical textual já sinaliza para uma matriz conceitual que coloca em debate o par textual ou discursivo e suas diferentes implicaçóes, seja no plano acadêmico/analítico (ROJO, 2005), seja na abordagem de ensino que se quer implementar em sala de aula.

Parece, de fato, que para atender a demanda ora anunciada, a seleçăo do termo textual é pertinente com relaçâo à cadeia enunciativa da proposiçâo didática que segue, uma vez que o termo possibilitaria convocar a ideia de uma dada tessitura linguística (ou tipo textual?), decerto, mais estável, mais próxima de um saber tipológico outrora já trabalhado no âmbito escolar, possível de ser presentificado (por via de diferentes dispositivos: fichas de ensino, textos, exercícios) e elementarizado (determinados aspectos sâo eleitos como objeto de estudo específicos), reelaborando, assim, "novos objetos de ensino", a partir de saberes e modelos já sedimentados (GOMES-SANTOS et al., 2014). O primeiro enunciado do boxe conclusivo reforça essa hipótese de trabalho, prestigiando o tipo: "O gênero textual lenda apresenta as seguintes características: É uma narrativa ficcional". As perguntas objetivas formuladas também sinalizam a preocupaçăo em presentificar e em elementarizar determinadas características da narrativa: "Qual é o enredo dessa narrativa? Qual é o espaço da narrativa? Qual é o tempo da narrativa? Constatamos aqui um procedimento didático mais ligado à exploraçăo de informaçōes relativas ao tipo textual narrativo, em lugar de uma prática de ensino voltada para trabalhar a leitura por um viés mais interpretativo, reflexivo, crítico, responsivo (ROJO, 2004).

Estaríamos, entǎo, diante de ecos de uma tradiçâo escolar da escrita como redaçăo voltada para trabalhar os tipos textuais (narrativo, descritivo, dissertativo), interligada à ideia de clareza, de precisāo, de avaliaçăo (GOMES-SANTOS, 2010), em que as condiçôes de produçâo de textos e os propósitos comunicativos săo diluídos em favor de um exercício de escrita, para fins institucionais específicos. Conforme Batista (1997), a aula de português nâo é construída apenas em funçâo do seu objeto, mas está sujeita às condiçôes e constriçōes de ordem histórica, social, institucional em que o evento aula está inserido. Por isso, năo podemos esquecer que o dispositivo didático está circunstanciado em um contexto socioinstitucional específico - a escola-usinaassumidamente comprometida com o objetivo de preparar os discentes para fazer uma redaçấo de vestibular e assim aprová-los nas melhores universidades e, "de quebra", nas primeiras colocaçóes dos cursos mais concorridos.

Dessa maneira, a escrita do professor apontaria para diferentes expectativas do trabalho docente: (i) ensinar gênero lenda, a fim de responder a toda uma expectativa 
de trazer a diversidade de vozes/ de dizeres dos discentes ao processo interativo em curso e a uma demanda de formaçăo, programas e regulamentaçôes direcionada à prática docente; (ii) ensinar o gênero redaçấo escolar, a fim de responder à expectativa institucional de ensinar a escrever para fins de avaliaçăo interna e externa, postura esta cobrada, exigida e fiscalizada pelos mecanismos de vigilância e de controle do fazer docente nestes contextos, que, inclusive, é monitorado por câmeras; (iii) ensinar lenda nos moldes da redaçăo escolar, a fim de responder a uma demanda dupla, prestigiando em alguma medida as possíveis relaçóes dialógicas e intergenéricas, que estes gêneros podem vir a estabelecer, conjugando assim duas grandes demandas: a oficial e a institucional. Segundo Andrade (2011, p. 1119), nestas circunstâncias: "Gêneros textuais extra-escolares ao adentrarem na escola, transformam-se em redaçóes, gêneros híbridos que se fundem para atingir um objetivo discursivo, linguístico e pedagógicos, ou seja, redaçóes miméticas.

Uma evidência dessas supracitadas relaçóes diz respeito às “orientaçóes do professor"37, que sinalizam a forte vinculaçáo da lenda com a arte de narrar, de contar. É interessante atentar que o texto escrito "A moça do táxi", escolhido para exemplificar a lenda urbana pressupóe a convocaçấo dos saberes da oralidade, do campo da cultura popular, em termos didáticos, esta leitura funcionaria como uma espécie de estímulo preparatório para a atividade escrita propriamente dita. Em seguida, temos a solicitaçâo de escrita que pede ao aluno: "sua leitura de mundo sobre o gênero textual lenda". Contudo, ao trazer este repertório para a escola, este sujeito deve estar atento para o molde escolar e uso da linguagem. O docente alerta para que o aluno "Escreva o mínimo de quinze e o máximo de trinta linhas" e "utilize a norma culta da língua portuguesa", muito embora o exemplo apresentado no dispositivo didático nâo siga esta "orientaçấo para produçăo textual".

Nessa perspectiva, os gêneros passariam por um processo de transformaçăo38, de adaptaçăo, para fins de adequaçăo a uma determinada versâo escolarizada que deveria "conter os traços característicos do gênero em questăo". Por isso, a estrutura geral da folha avulsa estaria adequada a esta demanda escolarizada, historicamente inscrita na cultura escolar. Em linhas gerais, a proposta está estruturada no sentido de: expor, caracterizar, exemplificar e exercitar. Isto retoma o que Chervel (1988) chama de ensino tradicional, caracterizado pela exposiçâo do mestre ou manual (exposiçâo do conteúdo, definiçôes); repetiçâo (reiteraçâo dos conceitos/exemplificaçōes); aplicaçâo de exercícios (o exercício é a contraparte essencial), avaliaçăo (necessidade de prestar atençăo - "Leia com atençăo o que a proposta de redaçăo solicita" - a fim de que as notas sejam boas, pois "para os casos de fuga ao tema, a nota é zero"). Vale lembrar que estes enunciados imperativos elencados no final da proposta, designados a "orientar",

37 Cabe lembrar que muitas orientaçôes referentes à lenda urbana sâo retiradas de um site da internet, mas nâo há nenhuma mençăo a esta fonte na folha avulsa.

38 Para Chevallard (1991), a transposiçâo didática consiste em um processo de transformaçăo e adaptaçăo pelo qual os objetos de ensino passam, desde os meios acadêmicos até a sua veiculaçấo nas salas de aula do ensino básico. A transposiçấo didática atua em instâncias distintas - propostas curriculares, livros didáticos, salas de aula - instâncias estas que, muitas vezes, apresentam interesses diversos. Refletir sobre essas diferentes dimensóes em que sáo configurados os processos de construçáo dos saberes escolares permite considerar nâo só uma visăo epistemológica, como também uma visấo social desses saberes. 
retomam a intençâo do ensino de escrita no seio escolar usineiro: instituir um padrâo uniforme para obter resultados parecidos por via de regras fixas, impessoais, gerais.

Mesmo diante do predomínio de modos cristalizados e normatizados de ensino de escrita no mundo usineiro, percebemos alguns indícios, de matrizes conceituais atreladas ao arcabouço teórico mais sofisticado para fins de didatizaçăo da escrita. Um exemplo disso é a espécie de preparaçăo, que antecede o lançamento da proposta de produçâo propriamente dita, a leitura de textos e de informaçóes como estratégia de subsídio, de preparaçáo, para o lançamento da atividade de escrita propriamente dita. Outro exemplo é o uso de determinados termos (gênero textual, produçăo textual, leitura de mundo), que săo transpostos das páginas dos documentos oficiais para constituiçăo do instrumento didático, ainda que alguns termos sejam veiculados de modo distante dos sentidos instituídos no âmbito acadêmico e dos saberes de referência. Năo obstante, de algum modo, este movimento implica mudanças do saber e do fazer docente/discente, muito embora, seja uma entrada polêmica, híbrida, mesclada para anunciar a realidade de idas e vindas, de mudanças e de permanências do ensino de Língua Materna na multifacetada cultura escolar brasileira.

Acreditamos que compreender a existência desta dinâmica é relevante tanto no sentido de refletir acerca dos modos de apropriaçăo dos saberes pelos professores da educaçăo básica e como articulam tais saberes às práticas efetivas de didatizaçăo dos gêneros textuais; quanto no sentido de buscar analisar as possíveis respostas dos discentes a este processo de ensino, levando em consideraçăo a possibilidade real de este sujeito apresentar uma lenda oriunda das esferas sociais em que está inserido, o que constitui uma entrada para a diversidade linguística e sociocultural regional por tantas vezes negligenciada pelos LDs.

\section{CONSIDERAÇÕES FINAIS}

Investigar a epistemologia do conhecimento escolar é condiçăo necessária e urgente, para que possamos conhecer as reais condiçōes de operacionalizaçáo e didatizaçáo dos saberes escolares. A breve análise sinaliza para o hibridismo teórico-metodológico da escrita professoral, que busca responder a diferentes demandas institucionais. Demandas estas, que sáo indiciadas e materializadas na escrita professoral e que, decerto, afetam os objetos, os modos e as ressonâncias do ensino de Redaçăo no seio escolar usineiro. Assim, o dispositivo didático produzido pelo docente permite a replicaçâo de saberes escolares já consagrados, como o ensino das tipologias textuais nos moldes didáticos de Redaçâo de Vestibular, mas também anuncia uma discreta possibilidade de convocaçấo das vozes e saberes dos alunos, situados num dado contexto sócio-histórico e ideológico.

Nessa direçâo, a relevância desta reflexâo sobre a escrita escolar reside no sentido de perceber que "a mescla de perspectivas vai ser o mais comum nas salas de aula durante um bom tempo: uma progressăo que ora segue critérios estruturais, tradicionais, ora segue critérios discursivos" (MENDONÇA, 2006, p. 218), o que encaminha a um distanciamento do iminente perigo de pensarmos a escola somente como palco de mera replicaçăo e reproduçăo dos valores ideológicos historicamente impostos. Urge, entâo, 
a necessidade de considerarmos esta agência de letramento como espaço de produçăo e de legitimaçăo dos saberes locais e globais (FERREIRA et al., 2014b). 


\section{REFERÊNCIAS}

ANDRADE, J. A. Redaçâo escolar: aspectos cognitivos de um gênero textual peculiar, 2011. Disponível em: <http://linguagem.unisul.br/paginas/ensino/pos/linguagem/ eventos/cd/Port/60.pdf.>. Acesso em: 29 abril 2015.

BACCEGA, M. A. Redaçôes no vestibular: uma abordagem sociolinguística. Cadernos de Pesquisa, Săo Paulo, n. 23, pp. 73-82, dez. 1977.

BAKHTIN, Ml. Marxismo e filosofia da linguagem: problemas fundamentais do método sociológico na ciência da linguagem. Traduçăo: Michel Lahud e Yara Frateschi Vieira. 9. ed. Sáo Paulo: Hucitec, 1995.

A cultura popular na Idade Média e no Renascimento: o contexto de François Rabelais. Săo Paulo: Hucitec, Brasília: da Universidade de Brasília, 1977/1999.

BARROS, K. S. M. Redaçăo escolar: produçăo textual de um gênero comunicativo? Leitura: teoria e prática, Campinas, ano 18, n. 34, pp. 13-22, 1999.

BATISTA, A. A. G. Aula de português: discurso e saberes escolares. Sáo Paulo: Martins Fontes, 1997.

BENJAMIN, W. Obras escolhidas. Rua de máo única. 3. ed. Săo Paulo: Brasiliense, 1993. v. 2. BUNZEN, C. Dinâmicas discursivas na aula de português: os usos do livro didático e projetos didáticos autorais. Tese. (Doutorado em Linguística Aplicada) INFORMAR FACULDADE. Universidade Estadual de Campinas, Campinas, 2009.

. Da era da composiçăo à era dos gêneros: o ensino de produçăo de texto no ensino médio.In: MENDONÇA, M.; BUNZEN, C. (Orgs.). Português no ensino médio e formaçáo de professor. Săo Paulo: Parábola, 2006, pp. 139-161. (Série Estratégia de Ensino).

BRASIL. Parâmetros Curriculares Nacionais: primeiro e segundo ciclos do ensino fundamental: língua portuguesa. Secretaria de educaçăo fundamental. Brasília: MEC/SEF, 1997.

Parâmetros curriculares nacionais: ensino médio. Secretaria de Educaçăo Média e Tecnológica. Brasília: Ministério da Educaçāo, 1999.

BRITO, C. M. C. A Linguagem do vestibulando: três aspectos. Belém, EdUFPA, 1995. 103 p.

.Um Estudo de regência na linguagem do vestibulando. Belém: EdUFPA, 1995.

BRITTO, Luis Percival Leme. A sombra do caos: ensino de língua x tradiçăo gramatical. Campinas: Mercado de letras, 1997.

CASCUDO, L. da C. Dicionário do Folclore Brasileiro. 9. ed. Brasília: José Olympio, INL, 1976.

CARONE, F. de B. O desempenho linguístico dos candidatos ao vestibular: concordância verbal. Cadernos de Pesquisa, Săo Paulo, n. 19, pp. 39-52, 1976.

CORRÊA, M. L. G. Relaçôes intergenéricas na análise indiciária de textos escritos. Trabalhos em Linguística Aplicada, v. 45, n. 2, pp. 205-224, 2006. 
CHERVEL, A. L" Histoire des disciplines scolaires: réflexions sur um domanine de recherches. Histoire d L"Éducation, Paris, n. 38, pp. 59-119,1988.

CHEVALLARD, Y. La transposición didáctica. Del saber sabio al saber enseñado. Buenos Aires: Aique Grupo Editor, 1991.

FERNANDES, M. do S. N. O desempenho linguístico dos candidatos ao vestibular: distribuiçăo dos demonstrativos. Estudo das formas este/esse. Cadernos de Pesquisa, São Paulo, n. 19, pp. 11-37, 1976.

FERREIRA, D. C. do N. Aula de português no Ensino Médio: a institucionalizaçăo de objetos gramaticais no trabalho docente. Dissertaçâo. (Mestrado em Linguística). Instituto de Letras e Comunicaçăo, Universidade Federal do Pará, Belém, 2008.

; LEAL, R. C. M.; RODRIGUES, I. C. F. S. Trabalho docente e didatizaçăo de gêneros discursivos: desafios e avanços no ensino de português para turmas numerosas. In: GOMES-SANTOS, s/n. Trabalho docente e linguagem em diferentes contextos escolares. Belém: Paka-tatu, 2014, pp. 71-93.

; SANTOS, N; PINHEIRO, S. Alfabetizaçăo e letramento: conceitos e práticas.In: FERREIRA, D. Letramento escolar: saberes e fazeres da docência. Belém: Grafitte, 2014b.

FURLANETTO, M. M. Práticas discursivas: desafio no ensino de língua portuguesa.In: BAGNO, M. Práticas de letramento no ensino: leitura, escrita e discurso. Sáo Paulo: Parábola, 2007.pp. 131-150.

GERALDI, J. W. Portos de Passagem. Săo Paulo: Martins Fontes, 1991.

GOMES-SANTOS, S. N. A escrita nas formas do trabalho docente. Educaçáo e Pesquisa, Sáo Paulo, v.36, n.2, pp. 445-457, maio-ago. 2010. Disponível em: <http:// www.scielo.br/pdf/ep/v36n2/a02v36n2>. Acesso em: 15 abril 2015.

et al. Trabalho docente e linguagem em diferentes contextos escolares. Belém: Paka-tatu, 2014.

GINZBURG, C. 0 queijo e os vermes: o cotidiano e as ideias de um moleiro perseguido pela Inquisiçấo. Sẫo Paulo: Companhia das Letras, 1987.

LEMOS, C. T. G. Redaçôes no vestibular: algumas estratégias. Cadernos de Pesquisa, São Paulo, n. 23, pp. 61-71, 1977.

LIMA, H. R. V. Redaçōes no vestibular: figuras de retórica. Desvios da língua comum? Cadernos de Pesquisa, São Paulo, n. 23, pp. 17-28, 1977.

MAMIZUKA, R. B. Redaçôes no vestibular: estudo do parágrafo, problemas de organizaçăo. Cadernos de Pesquisa, Sâo Paulo, n. 23, pp. 37-42, 1977.

MENDONÇA, M.; BUNZEN, C. (Orgs.). Português no ensino médio e formaçăo do professor. Săo Paulo: Parábola Editorial, 2006.

NEGRÂO, E. V. Redaçōes no vestibular: utilizaçâo do léxico: estudo dos adjetivos. Cadernos de Pesquisa, Săo Paulo, n. 23, pp. 9-15, 1977.

OSAKABE, H. Redaçôes no vestibular: provas de argumentaçâo. Cadernos de Pesquisa, Sáo Paulo n. 23, pp. 51-59, 1977.

PÉCORA, A. A. B. Redaçôes no vestibular: estudo do período: uma proposta pragmática. 
Cadernos de Pesquisa, Sáo Paulo, n. 23, p. 29-36, 1977.

Problemas de Redaçăo. São Paulo: Martins Fontes, 1989.

PIETRI, E. Sobre a constituiçâo da disciplina curricular de Língua Portuguesa. Revista Brasileira de Educaçăo, v. 15, n. 43, jan.-abr. 2010. Disponível em: <http://www.scielo.br/ pdf/rbedu/v15n43/a05v15n43.pdf>. Acesso em: 03 mar.2015.

PINO, M. A. B. D et al. Trabalho Docente, controle e intensificaçăo: câmaras, novo gerencialismo e práticas de governo. In: FIDALGO, F et al. A intensificaçăo do trabalho docente: tecnologias e produtividade. Campinas: Papirus, 2009.

RAZZINI, M. 0 espelho da naçáo: a antologia nacional e o ensino de português e de literatura (1838-1971). INFORMAR ANO DE CONCLUSĀO, NÚMERO DE FOLHAS. Tese. (Doutorado em teoria literária). IEL, Campinas, 2000.

ROCCO, M. T. F. Crise na linguagem: a redaçăo no vestibular. Sâo Paulo: Mestre Jou, 1981.

ROJO, R.; CORDEIRO, G. S. Apresentaçăo: gêneros orais e escritos como objetos de ensino: modo de pensar, modo de fazer.In: SCHNEUWLY, B; DOLZ, J. (Orgs.). Gêneros orais e escritos na escola. Traduçấo: (Org.). Roxane; Rojo;Glaís Sales Cordeiro. Campinas: Mercado de Letras, 2004.

Gêneros do discurso e gêneros textuais: questóes teóricas e aplicadas. In: Meurer, J. L., Bonini, A., Motta-Roth, D. (Orgs.). Gêneros: teorias, métodos, debates. Săo Paulo: Parábola, 2005.

SARMENTO, L. L. Oficina de redaçăo. São Paulo: moderna, 2006.

SAUTCHUK, I. A produçăo dialógica do texto escrito: um diálogo entre escritor e leitor interno. Săo Paulo: Martins Fontes, 2003.

SILVA, E. T. da. Criticidade e leitura: ensaios. Campinas: Mercado de Letras: Associaçăo de Leitura do Brasil (ALB), 1998.

SOARES, M. Linguagem e escola: uma perspectiva social. 17. ed. Sáo Paulo: Ática, 2002a.

Português na escola - história de uma disciplina curricular.In: BAGNO, M. (Org.).

Linguística da norma. Săo Paulo: Loyola, 2002b. p. 155-177.

Um olhar sobre o livro didático. Presença Pedagógica, Belo Horizonte, v. 12, n. 12 , pp. 53-63, nov.-dez., 1996.

A Escolarizaçăo da Literatura Infantil e Juvenil.In: EVANGELISTA, Aracy Alves Martins; BRANDẢO, Heliana Maria Brina; MACHADO, Maria Zélia Versiani (Orgs.). Escolarizaçăo da Leitura Literária. 2. ed. Belo Horizonte: Autêntica, 2003. pp. 17-48.

SCHNEUWLY, B.; CORDEIRO, G. S.; DOLZ, J. A la recherche de l»objet enseigné: une démarche multifocale. Les dossiers des sciences de l»éducation, n. 14, pp. 77-93, 2006.

Le travail enseignant.In: SCHNEUWLY, B.; DOLZ, J. (Orgs.). Des objets enseignés en classe de français - Le travail de l"enseignants la rédaction de texts argumentatifs et sur la subordonnée relative. Rennes, FR: Presses Universitaires de Rennes, 2009. pp. 29-43.

SCHNEUWLY, B.; Dolz, J. Gêneros Orais e Escritos na Escola. Traduçâo: Roxane Rojo, 
Glaís Cordeiro. Campinas: Mercado de Letras, 2004.

TARDIF, M. Saberes docentes e formaçăo profissional. 2. ed. Petrópolis: Vozes, 2002.

; LESSARD, C. $\mathbf{O}$ trabalho docente: elementos para uma teoria da docência como profissăo de interaçōes humanas. Rio de Janeiro: Vozes, 2005.

TRAVAGLIA, L. Cs. Gramática e interaçăo: uma proposta para o ensino de gramática no primeiro e segundo graus. Sáo Paulo: Cortez, 1996.

VAL, M. da G. C. Redaçăo e Textualidade. Săo Paulo: Martins Fontes, 1991.

VIANNA, H. M. Redaçăo e medida da expressăo escrita: algumas contribuiçôes da pesquisa educacional. Cadernos de Pesquisa, Săo Paulo, n. 16, pp. 41-47, 1976.

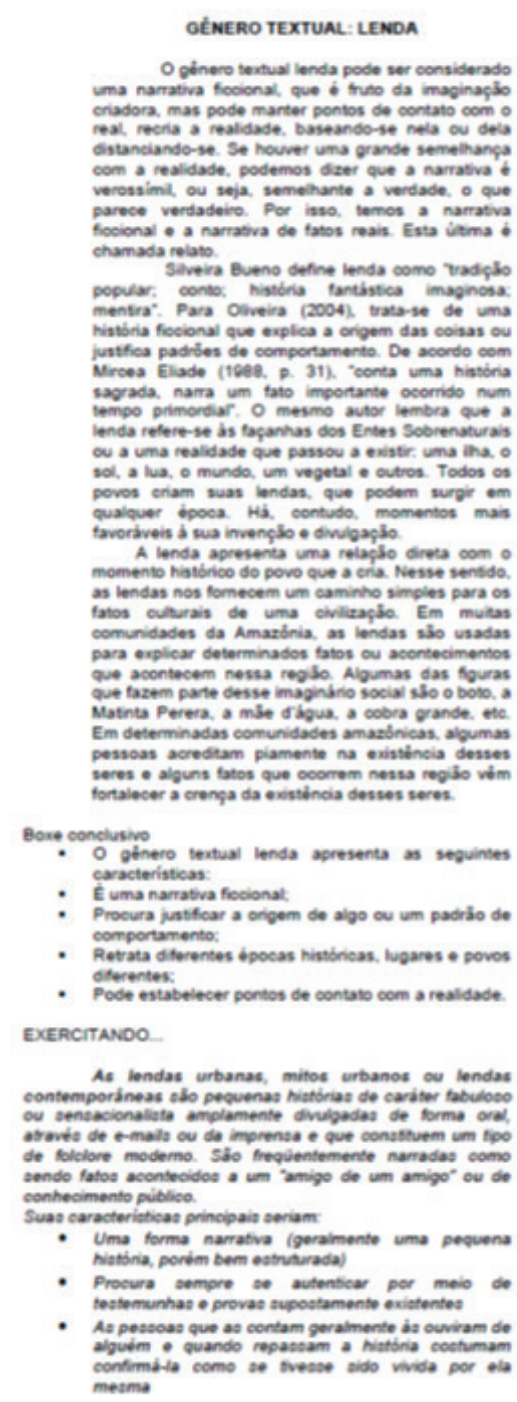

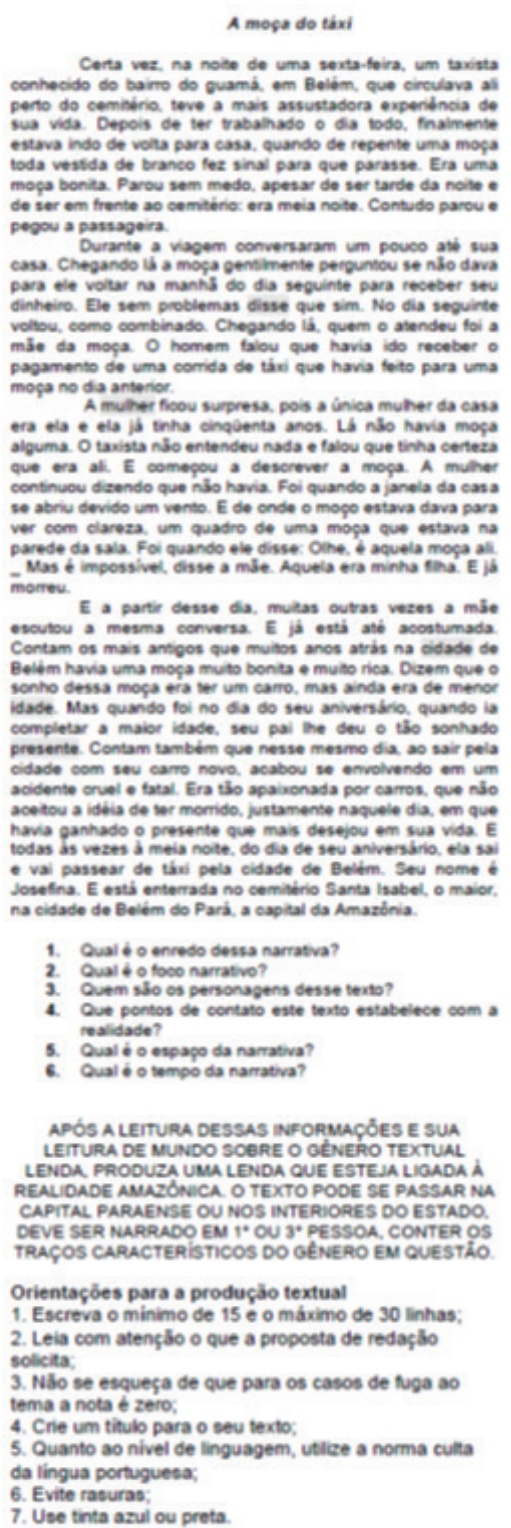

